\title{
Indigenous Therapeutics of Alzheimer: A Review of Ayurvedic Herbs from its Ethnobotany to Phytotherapy
}

\author{
Deeksha Sharma ${ }^{1 \mathbb{D}}$, Sakshi Tyagi ${ }^{2}$, Siddhartha Dan ${ }^{3, * \mathbb{D}}$, Mohit Pant ${ }^{4 \mathbb{D}}$, Arun Kumar 5,*(D) \\ Shoolini University of Biotechnology and Management Sciences, Shoolini University, Solan; Himachal Pradesh; India \\ Department of Biotechnology, Jaypee Institute of Information Technology, Noida; Uttar Pradesh; India \\ Department of Biotechnology, I.K. Gujral Punjab Technical University, Jalandhar; Punjab; India \\ Department of Pharmacovigilance, Paraxel International Pvt. Ltd., Mohali; Punjab; India \\ Molecular Biology Lab, Drug Standardisation Unit, Dr. DP Rastogi Central Research Institute of Homeopathy, Ministry \\ of AYUSH, Govt. of India, Noida; Uttar Pradesh; India \\ * Correspondence: siddharthadan7@gmail.com (S.D.); arun.2k.64@gmail.com (A.K.);
}

Scopus Author 57218994496

Received: 31.08.2021; Revised: 15.10.2021; Accepted: 18.10.2021; Published: 31.10.2021

\begin{abstract}
Ayurveda, often known as Ayurvedic medicine, is a customized system of the traditional system of medicine with historical roots in the Indian subcontinent. This alternative medicine system has been used for more than 5,000 years in India, and it is grounded on a holistic view of treatment that stimulates and supports equilibrium in diverse facets of human life: the body, soul, and mind. A great variety of herbs and plants are used in Ayurveda for numerous advantages; however, the popular Ayurvedic medicinal plants and formulations that are used to delay the aging of the human brain and improve memory consist of Ashwagandha (Withania somnifera), Turmeric (Curcuma longa), Brahmi (Bacopa monnieri), Shankhpushpi (Convolvulus pluricaulis, Evolvulus alsinoides, and other species), gotu kola (Centella asiatica), and guggulu (Commiphora mukul and correlated species) and a preparation identified as Brāhmī Ghṛita, containing Brahmi, Vacā (Acorus calamus), Kuștha (Saussurea lappa), Shankhpushpi, and Purāṇa Ghrita (old clarified butter/old ghee). One of the extremely common progressive neurodegenerative disorders is Alzheimer s disease (AD), which is characterized by profound memory loss ample enough to hinder social and occupational functioning. Globally, more than 20 million people are affected by this most common form of dementia. AD is characterized by a stealthy loss of memory, allied functional decline, and behavioral disturbances. With modern scientific methods, it is anticipated that this description can be further explored to disclose novel therapeutic pointers and push-start additional studies on the use of Ayurvedic medicine to prevent and treat AD. This paper reviews the clinical effects of a number of generally used types of herbal medicines to treat $\mathrm{AD}$.
\end{abstract}

Keywords: Alzheimer's disease; Bacopa monnieri; Withania somnifera; Convolvulus pluricaulis; Curcuma longa L.

(C) 2021 by the authors. This article is an open-access article distributed under the terms and conditions of the Creative Commons Attribution (CC BY) license (https://creativecommons.org/licenses/by/4.0/).

\section{Introduction}

Throughout the life span, many diseases affect the human body with suitable remedies available in nature. When synthetic medications fail to be effective or show severe side effects, they are a natural medicinal system sourced from plants that provide safety and comfort to patients during therapy. It has been clinically demonstrated that synthetic drugs used in the treatment of hypertension show adverse effects on the mental fitness of patients. [1]. 
Since the Vedic age, in India, ancestral knowledge of medicinal plants has been passed down through generations like the other four knowledge texts (Vedas) in ancient India. Due to the great mind of the sages of "Gurukul," Ayurveda, which was drawn from the Atharvaveda, grew into a well-established medicinal system. The effect of Ayurveda (which dates back to the Indus Valley Civilization period, around 3000 BC) on people's minds was so strong in our country that even the Middle East and Europe couldn't match it in terms of popularity among Indians and people in adjacent nations. In a few days, the development of medicine is based on Ayurveda's reverse pharmacology in which drug candidates are primarily recognized based on their traditional therapeutic experience, followed by validation through clinical experiments. Prior studies [2-4] have found widespread or meticulous knowledge of therapeutic plants effective in mental diseases, but a total accumulation incorporating Ayurveda prescriptions, botanical, and synthetic elements of plants is unlikely. It was our continued interest in chemical and biological medicines and aromatic herbs [5-9], which led to writing this article on several plants prescribed in Ayurvedic medicine for brain diseases [10]

Ayurveda understands the basic principle of five great elements, "Pancha Maha Bhutas" and emphasizes that fault, tissue, and impurity must be in perfect symmetry with all five elements used to create the human physique, and the first element is known as, earth (bhumi/prithvi): bones \& organs, water (varuna/jal): Blood, fire (agni): Heat of the Body, air (vayu) and space (dyaus/akash): astral body. As a result, a balance between the three elemental energies is required, i.e., Vata (mixture of air and Ether, i.e., wind), Pitta (mixture of fire and water, i.e., bile), and Kapha (mixture of water and earth, i.e., phlegm). According to Ayurveda, if these three energies are in a balanced state or are present in the same quantity, the body will stay well; otherwise, it will get sick in various ways [11]. This is based on a holistic pattern to heal that stability and benefits multiple perspectives of human life, body, mind, and soul [12].

The other four knowledge texts (Vedas) of ancient India include the Rigveda, Yajurveda, Samaveda, and Atharvaveda, whose compositions date back to the 12th and 7th centuries BCE. More than 5000 signs and symptoms of various diseases have been described in Ayurvedic medicine with 700 herbs and 6,000 yogas treatment options. Dementia with symptoms of amnesia and memory loss has not been directly mentioned in Ayurvedic literature. However, symptoms of amnesia and memory loss are well documented. [12]. Many ayurvedic herbs and their properties have been used to remedy various nervous system disorders like memory loss in older adults, unconsciousness, and undeveloped brains.

The effects of medicinal plants on the central nervous system's disorders in these machines Only mechanical studies have been done to determine their effects on diseases such as Alzheimer's [13]. In recent times, there has been increased engagement in the use of phytochemicals for the remedying of dementia. The pharmacological treatment of dementia exploiting drugs like haloperidol, risperidone, aripiprazole, and olanzapine is repeatedly unimpressive and has many side effects [14-20]. This article's primary objective is to give an in-depth description of the signaling transduction processes and molecular mechanisms of certain Ayurvedic therapeutic plants used to treat dementia. This is estimated that this information can be outlined with modernized scientific validation approaches to disclose novel therapeutic leads and initiate further investigations on the use of Ayurvedic medication to inhibit and treat dementia [21].

This application of equivalent herbs and drugs such as plant extracts in dementia therapy fluctuates according to different cultural traditions. Ayurvedic restorative flavors change the neuro-endocrine-safe systems and are similarly rich wellsprings of cell fortifications 
and moderating mixtures $[22,23]$. They are proclaimed to improve memory and reestablish scholarly limits [24-26]. A couple of Ayurvedic drugs have been mishandled for the treatment and the leading group of extreme and steady neurological ailments. Examples of notable Ayurvedic drugs include Brāhmī Ghṛita, Divya Medha Kwath, and Brento Strength. These definitions instigate ramifications for mind limits, such as development in the circulatory system and backing of memory [13].

The nervous system and its abnormalities are the subjects of a whole body of material in Ayurveda. Nervous system disorders, which in Sanskrit are called 'Vata Vyadhi' [mentioned in verse 5 [26-27] of the Ashtangahridayasamhita (Sutra Sthana) by Vāgbhața], Vata imbalance, biological air humor, energy moving through the brain, and nerves, i.e., the ancients contemplated nerve impulses to travel through the body or a type of wind, both voluntary and involuntary actions are under control were believed to be brought on. Therefore, Vata pathology always includes some weakness, disturbances, or a nervous system hypersensitivity. These texts include direct evidence of age-related loss of memory, prevention of disease, and medical intervention. Those manuscripts describe the application of various herbs and their characteristics and energy for nervous system diseases. Loss of memory is usually observed in more adults, but more currently in nervous system disorders and dementia. The role of these herbs has been investigated mechanically, including dementia, Alzheimer's is associated with diseases [27]. Admittedly, many scientific investigations have inscribed the use of 'nervines' and their components to different ayurvedic therapeutic plants for strengthening the functional activity of the nervous system and the restoration of memory [27,28].

Originally, Alzheimer's disease (AD) was once known as presenile dementia, defined as an acquired mental disorder characterized by a loss of intellectual capacities that interfered with social or occupational functioning. It's linked to cell loss and brain shrinkage in specific brain areas, primarily the basal forebrain and hippocampus. A significant role is played by the $\beta$-amyloid peptide (BAP) in the progress of this progressive brain disorder.

Unfortunately, synthetic drugs are not able to cure $\mathrm{AD}$; however, to some extent, they can help manage it to some extent. Numerous studies have shown that natural antioxidants, including vitamin $\mathrm{E}$ and $\mathrm{C}$ as well as beta-carotene, can help scavenge free radicals produced during the evolution of this disease. The lack of acetylcholine, a nerve transmitter, is thought to be the cause of memory loss. It is possible to boost the level of this transmitter in the brain by limiting the action of the enzyme acetylcholinesterase, which splits or breaks down the transmitter material. Synthetic medications that prevent the breakdown of the messenger or transmitter acetylcholine could help slow the progression of this neurodegenerative disease $[29,30]$.

\section{Search Method}

This survey incorporates investigations of Alzheimer's disease and Traditional herbal medicines utilized in the treatment distributed in the English language. The EMBASE databases were explored through PubMed and Google Scholar. During the search, keywords comprising of "Alzheimer's disease" and "herbal medicines", "ethnobotany", or "phytotherapy" were used to collect the scientific information related to alzheimer's disease. At the same time, different keywords like "Ayurveda", "Vedic" and "Neurological Disorders" were also utilized in search of potential therapeutics. The inputs of these keywords were data from different sources related to neurological disorders. However, much data about Alzheimer's disease treatment by Traditional herbal medicines could be expected without ignoring related inquiries. 


\subsection{Medicinal plants.}

\subsubsection{Bacopa monnieraWettst. (Brambhi).}

Goswami et al. evaluated the impact of Bacopa monnieri (Brahmi), which is correlated with the Ayurvedic arrangement of medication on the intellectual functions in AD patients. Finally, it was concluded that it might be advantageous in these patients; nevertheless, more research is still required [31].

It comprises sterols, saponins, alkaloids, monnierin, hersaponin acid A, herpestine, and brahmine [32]. In order to treat memory disorders and AD, Bacopa monnieri, in combination with Centellaastiatica and Evolulusalsinoides has been used as traditional healers [33]. Bacopa monnieri plant is adaptogenic, neuroprotective, antimicrobial and memory enhancer [34]. Carlo et al. (2008) [35] reported the efficacy of Bacopa monnieri on cognitive abilities performance, anxiety disorder, and depressive disorder in old age patients. An additional study verified that Bacopa monnieri obstructs cholinergic degeneration and shows cognition-enhancing activity in a rat model of $\mathrm{AD}$ [36]. This plant encompasses numerous phytocompounds, principally bacosides $\mathrm{A}$ and $\mathrm{B}$, bacopasides III to $\mathrm{V}$, and bacosaponins $\mathrm{A}, \mathrm{B}$, and $\mathrm{C}$, jujubogenin, bisdesmosides, bacopa saponins D, E, and F, and sulfhydryl compounds that contributed to its antioxidant activity [37]. Extracts of B. monnieri have been widely explored for their neuropharmacological influence and nootropic actions [38].In hippocampus, B. monnieri upsurge the protein kinase activity, which contributes to its memory-enhancing properties [39]. According to a study, cognitive deficits were reversed by standardized B. monnieri, which are induced by the administration of colchicines and isobotenic acid intracerebroventricularly into nucleus basalis magnocellularis [40]. Neurons treated with B. monnieri extract exhibited lesser reactive oxygen species levels, which suggested that $B$. monnieri restrained intracellular oxidative stress [41]. Brahmi, also called B. monnieri, is a bitter-tasting creeper plant that grows in wet and marshy locations. That is used in the Ayurvedic system of medicine as a nerves tonic, diuretics, and cardioprotective, as well as a treatment for bronchial asthma, insomnia, seizure disorder, and rheumatic disorders [42,43].

Saponins and triterpenoid bacosaponins, which contain bacosides A and B, bacosaponins A, B, and C, and bacopasides III through V, are the main components of Bacopa monnieri (BM). The jujubogenin bisdesmosides bacopa saponins $\mathrm{E}, \mathrm{D}$, and $\mathrm{F}$ are supplementary saponin glycosides. Plant sterols, alkaloids, polyphenols, betulin acid, and sulfhydryl compounds are among the other antioxidant ingredients [42, 43].

Therefore, B. monnieri may reduce divalent metals, scavenge reactive oxygen species, reduce the generation of lipid peroxides, and limit lipoxygenase activity [44]. BM was traditionally utilized to improve memory and cognitive function [45]. The neuropharmacological effects and nootropic effects of BM extracts have been extensively studied [43, 45, 46]. In section 2.1.2, the mechanisms that underpin the development of neuronal degeneration are discussed [47].

\subsubsection{The neuropharmacological activity of Bacoside A.}

Numerous studies urged that B. monnieri's bioactive elements (i.e., bacosides) defend the brain against aerophilic hurt and age-related psychological feature deterioration with several mechanisms of action [47-49]. In addition, bacosides stop $A \beta$ aggregation and formation of fibrils [50] additionally as defend neurons against $A \beta$-induced toxicity [51]. From 
superior liquid activity (HPLC) analysis, the bioactive constituent, bacoside A, was gift among the B. monnieri extract (BME)-treated rat body substance and can directly or indirectly move with the organic compound systems to spice up memory and intelligence [52]. Bacosides gift in B. monnieri unit sometimes nonionic glycosides, [53] that amendment it to cross the barrier (BBB) via straightforward lipid-mediated passive diffusion [54].

In the same way, the bioavailability in the brain has been acknowledged by the radiopharmaceuticals' areas of biology [55]. De et al., with the help of an animal model, described BME as being capable of varying the uptake of the radioactivity of $99 \mathrm{mTc}$-labeled ethylene dicysteine diethyl ester (99mTc-ECD) and 99mTc-labeled cystine dimethyl ester (99mTc-CDM) in the brain and other body parts. An exaggerated and extensive uptake $(\mathrm{P}<.05)$ of $99 \mathrm{mTc}-\mathrm{CDM}$ and $99 \mathrm{mTc}-\mathrm{ECD}$ in the brain and other organs after treatment with $\mathrm{BME}$ was discovered in the ultimate results. As BME is a worthy antioxidant and has cognitive function on human memory, these outcomes have evaluated pharmacokinetic interactions of BME and put forward that BME can perform on the biodistribution of 99mTc-ECD and 99mTc-CDM in specific organs [55].

Similarly, clinical studies have also exhibited that oral treatment with B. monnieri could improve memory in both children as well as adults. Watkins' experiments [56] looked at the effects of B. monnieri supplementation on hepatic and intestinal P-glycoprotein (Pgp) levels as well as Cytochrome 3A (CYP3A) expression levels. According to him, alone, Pgp-mediated efflux and Cytochrome P450 (CYP45O)-mediated metabolism play a crucial part in modulating the oral bioavailability of the corresponding drug. However, following a week of B. monnieri administration, the mRNA expression level and functional activity of CYP3A4 and modifications in Pgp in the gut and liver of male Sprague Dawley (SD) rats were examined. The outcome revealed that depending on the testosterone hydroxylase catalytic activity in the liver and intestine, B. monnieri down-regulated both intestinal Pgp and CYP3A expression levels [57]. Additional studies also presented that in vivo pharmacokinetic interaction between digoxin (Pgp substrate) and carbamazepine (CYP 3A substrate) alongside the pharmacokinetics of Pgp and CYP3A probed drugs could be modified by administration of extract of B. monnieri in male SD rats. Probe drugs are identified to diminish both biological and technical risk factors of tracking a specific target to be selective as well as potent to their target. The results indicated that treatment with B. monnieri and carbamazepine triggered a modification in the carbamazepine pharmacokinetic profile with a noteworthy increase in Cmax (maximum serum concentration of the drug achieved within the plasma) and AUC (the space underneath the plasma drug concentration-time curve) $(0-\infty)$ also reduction in $\mathrm{CL} / \mathrm{F}$ (apparent total clearance of the drug from plasma when oral administration) opposing to the vehicle management rats [58].

\subsubsection{Withania somnifera (Aswhaganda).}

The active glycowithanolides in Withania somnifera (Ashawgandha) have a notable antioxidant potential, boosting superoxide dismutase, catalase, and glutathione peroxidase activities [59]. The colorimetric approach based on Ellman's reaction was used to determine the level of cholinesterase inhibition.

The study demonstrates that AChE was inhibited significantly by W. somnifera extract in a concentration-dependent manner [60]. W. somnifera belongs to the family of Solanaceae, the root of this plant is extensively used. It has free radical scavenging and antioxidant properties and also helps in the enhancement of the immune system [61]. W. somnifera 
possesses a calming effect, although other adaptogens tend to stimulate and thus show positive effects in individuals with Alzheimer's disease [62]. A recent study of $W$. somnifera showed a reduced level of stress and failure to concentrate, and memory loss can be reversed in a dosedependent system, and no adverse effects were found [63].

More than a few phytocompounds present in W. somnifera that comprises withanolides A to $\mathrm{Y}$, withasomniferin $\mathrm{A}$, withasomidienone, withaferin $\mathrm{A}$, withasomniferols $\mathrm{A}$ to $\mathrm{C}$, dehydrowithanolide R, and withanone, phytosterols sitoindosides VII to X, amino acids betasitosterol, alkaloids, and great amounts of iron [64]. Withanamides that were created during the Alzheimer's disease origination and development exhibited free radicals scavenging activity.

It obstructed the demise of neuronal cells triggered by amyloid plaques [65]. Molecular modeling research displayed that amides $\mathrm{A}$ and $\mathrm{C}$ predominantly bind to $\beta$-amyloid (A $\beta 25$ 35) active motif and averts the construction of fibril [66]. Aqueous extracts of W. somnifera showed improvement in the cholinergic activity of rats by increasing the acetylcholine content and choline acetyl transferase activity. This indicates the memory-improving and cognitionimproving benefits [67].

Withania somnifera shows antioxidant and free radical scavenging properties, as well as the ability to support a healthy immune system, central nervous system against Alzheimer's disease [69].

According to recent gold standard of epidemiologic (randomized, double-blind placebo control) studies of Ashwagandha's effects on stress, it lowered stress symptoms, and incapability to focus and reversed poor memory in a dose-dependent system, with 500 milligrams per day being more effective [63]. Furthermore, no adverse effect was observed. Free radicals created during the onset and progression of $\mathrm{AD}$ have been demonstrated to be scavenged by a subset of these components (withanamides).

Withanamides also blocked neuronal cell death and were triggered by amyloid plaques $[62,65,70,71]$. In the CNS, memory, and learning have been reported to increase by Ashwagandha [72].

In rats, aqueous preparations of this plant increased cholinergic activity, acetylcholine concentration, and choline acetyltransferase activity, which could explain the cognitionenhancing and memory-improving effects to some extent $[67,73]$.

Following treatment with a methanol extract of Ashwagandha, both axons and dendrites showed significant regrowth. The in vivo effects of Ashwagandha was maintained long after the medicine was stopped being used. In contrast to J20 mice fed only traditional chow, initial studies from this lab revealed significant neurogenesis in the dentate gyrus region in J20 mice that express the mutant form of human amyloid precursor protein (APP) that bears both the Swedish (K670N/M671L) and the Indiana (V717F) mutations - that were fed a diet containing the complete herb (Ashwagandha root powder, 2.5 gram per kg body weight) (unpublished data). Although the herb has been used effectively in Ayurvedic medication for eras, a scientific studies of the chronic or acute toxic effects or its many parts continues to be deficient. Supplementary studies are necessary to confirm the therapeutic significance of this herb [69].

\subsubsection{Convolvulus pluricaulis (Sankopuspa).}

So far, several species for Shankapushpi have been described, including Convolvulus pluricaulis (CP), Convolvulus microphyllus, Evolvulusalsinoides, and Clitoriaternatea (CT). Shankhpushpi is one of the commonly found plants in India. As a nervine tonic, the whole plant 
of shankhpushpi has been used in several formulae to enhance memory and cognitive function [71, 74-76]. Tri terpenoids, flavonol glycosides, anthocyanins, and steroids are a few examples of secondary metabolites that may be accountable for pharmacological, nootropic, and memory-improving characteristics shankhpushpi $[76,77]$. Furthermore, it is recommended for nerve problems such as mental tiredness, depression, anxiety disorder, and insomnia (sleep disorder) $[76,78,79]$. When tested in vitro, the ethanolic extract of CP possesses significant antioxidant activity $[71,75,80,81]$. Mice administered with $\mathrm{CP}$ extracts showed improvement in their memory in a dose-dependent manner. The administration of CT's aqueous root extract to infant rat pups resulted in improved memory and abstraction learning performance, indicating that CT has memory-enhancing properties. Furthermore, in comparison to agematched controls, CT-treated rats' hippocampi had a significant rise in acetylcholine concentration.

An increase in acetylcholine concentration in the hippocampus could be the neurochemical basis for their better learning and memory [82-84].

It encompasses convoline, convosine, convolidine, convolvine, confoline, kaempferol and steroids phytosterol [85]. Convolvulus pluricaulis (CP) is a member of the Convolvulaceae family. It is used as a memory-improving agent. As per an additional study conducted by Bihaqi et al. (2011) [75], it was indicated that extracts of CP improve memory in Wistar rats in a dosedependent manner. In the same way, giving mice $\mathrm{CP}$ for one week improved their memory. [86].

In a publication [87], the Indian Council of Medical Research (ICMR) established quality requirements for $C$. pluricaulis medication. Despite the fact that these plants' scientific potential in central nervous system depression disorders, anxiolytic, tranquilizing, antidepressant, antistress, neurodegenerative, antiamnesic, antioxidant, hypolipidemic, immunomodulatory, analgesic, anti-fungal, antibacterial, antidiabetic, antiulcer, anticatatonic, and cardiovascular activity has been demonstrated. These are said to include a variety of alkaloids, flavonoids, and coumarins as active compounds that cause biological effects [88]. Table 1 [89-104] and Table 2 [105] show the preliminary pharmacological activity of ethanolic extracts of $C$. pluricaulis (leaves). We conclude that Alzheimer's disease (AD) is one of the most complex neurodegenerative diseases in humans [106], referring to a specific onset and course of cognitive and functional deterioration coupled with changes in specific neuropathology [107].

Table 1. Preliminary pharmacologic activities of $C$. pluricaulis ethanolic extracts (leaves).

\begin{tabular}{l|l|l|l}
$\begin{array}{l}\text { Plant } \\
\text { part/extract }\end{array}$ & Dose/model & $\begin{array}{l}\text { Standard Drug ( } \\
\text { Activity) }\end{array}$ & Result \\
\cline { 1 - 2 } $\begin{array}{l}\text { Whole part of } \\
\text { plant/chloroform }\end{array}$ & $\begin{array}{l}84 \%, 83 \%, 48 \% / 1,1-d i p h e n y l- \\
\text { 2-picryl- hydrazyl model }\end{array}$ & $\begin{array}{l}\text { Ascorbic acid } \\
\text { (Antioxidant } \\
\text { activity) }\end{array}$ & $\begin{array}{l}\text { When evaluated in vitro, the } \text {. } \text { pluricaulis extract has strong } \\
\text { anticonvulsant efficacy. }\end{array}$ \\
\cline { 2 - 3 } $\begin{array}{l}\text { Whole part of } \\
\text { plant/methanolic }\end{array}$ & $\begin{array}{l}41 \mathrm{pg} / \mathrm{mL} / 1,1 \text {-diphenyl-2- } \\
\text { picryl- hydrazyl model }\end{array}$ & $\begin{array}{l}\text { The extract of } \text {. } \text { pluricaulis had a considerable free radical } \\
\text { scavenging action. }\end{array}$ \\
\cline { 2 - 3 } & $\begin{array}{l}500,1000 \mathrm{mg} / \mathrm{kg} / \text { Maximal } \\
\text { electroshock model }\end{array}$ & $\begin{array}{l}\text { Phenytoin } \\
\text { (Anticonvulsant } \\
\text { activity) }\end{array}$ & $\begin{array}{l}\text { At this dose, the } \text {. pluricaulis extract did not completely } \\
\text { eliminate hind limb extension, but it did shorten the time it took } \\
\text { to recover from a convulsion. }\end{array}$ \\
\hline $\begin{array}{l}\text { Whole part of } \\
\text { plant/ethanolic }\end{array}$ & $\begin{array}{l}50,100 \mathrm{mg} / \mathrm{kg} / \text { Tail suspension } \\
\text { test and forced swim test model }\end{array}$ & $\begin{array}{l}\text { Imipramine or } \\
\text { fluoxetine } \\
\text { (Antidepressant } \\
\text { activity) }\end{array}$ & $\begin{array}{l}\text { In both the Tail suspension test and the Forced swim test, only } \\
\text { the chloroform portion in these doses significantly reduced the } \\
\text { immobility time. }\end{array}$ \\
\hline $\begin{array}{l}\text { Aerial part of } \\
\text { the } \\
\text { plant/ethanolic }\end{array}$ & $\begin{array}{l}200 \mathrm{mg} / \mathrm{kg} / \text { Elevated plus-maze } \\
\text { model }\end{array}$ & $\begin{array}{l}\text { Diazepam } \\
\text { (Anxiolytic } \\
\text { activity) }\end{array}$ & $\begin{array}{l}\text { The results demonstrated that at this dose, ethyl acetate } \\
\text { fractions impaired neuromuscular coordination, which is a sign } \\
\text { of muscle relaxant activity. }\end{array}$
\end{tabular}




\begin{tabular}{|c|c|c|c|}
\hline $\begin{array}{l}\text { Plant } \\
\text { part/extract }\end{array}$ & Dose/model & $\begin{array}{l}\text { Standard Drug ( } \\
\text { Activity) }\end{array}$ & Result \\
\hline $\begin{array}{l}\text { Flower part of } \\
\text { the } \\
\text { pnat/ethanolic }\end{array}$ & $\begin{array}{l}100,200,400 \mathrm{mg} / \mathrm{kg} / \text { Elevated } \\
\text { plus maze model }\end{array}$ & & $\begin{array}{l}\text { The results showed that the plant's floral extract had an } \\
\text { anxiolytic effect in rats in the Elevated plus-maze. }\end{array}$ \\
\hline $\begin{array}{l}\text { Whole part of } \\
\text { the } \\
\text { plant/methanolic }\end{array}$ & $\begin{array}{l}\text { Staphylococcus aureus } 6538, \\
\text { Escherichia coli } \text { ATCC } \\
\text { 8739/Cup plate Model }\end{array}$ & $\begin{array}{l}\text { Tetracycline } \\
\text { (Antibacterial } \\
\text { activity) }\end{array}$ & $\begin{array}{l}\text { In comparison to Staphylococcus aureus, } C \text {. pluricaulis extract } \\
\text { was found to be more potent against Escherichia coli. }\end{array}$ \\
\hline $\begin{array}{l}\text { Whole part of } \\
\text { the } \\
\text { plant/aqueous }\end{array}$ & $\begin{array}{l}150 \mathrm{mg} / \mathrm{kg} / \mathrm{scopolamine-} \\
\text { induced increased tau and } \\
\text { amyloid precursor protein }\end{array}$ & $\begin{array}{l}\text { Rivastigmine } \\
\text { (Antiviral activity) }\end{array}$ & $\begin{array}{l}\text { In comparison to the scopolamine-treated group, } C \text {. pluricaulis } \\
\text { extract lowered elevated protein and mRNA levels of tau and } \\
\text { Amyloid } B \text { precursor protein levels, followed by a drop in } A B \\
\text { levels. }\end{array}$ \\
\hline \multirow[t]{2}{*}{$\begin{array}{l}\text { Whole part of } \\
\text { the } \\
\text { plant/ethanolic }\end{array}$} & $\begin{array}{l}250,500 \mathrm{mg} / \mathrm{kg} / \mathrm{Cook} \text { and } \\
\text { Weiil ley's pole climbing model }\end{array}$ & $\begin{array}{l}\text { Piracetam } \\
\text { (Nootropic } \\
\text { activity) }\end{array}$ & $\begin{array}{l}\text { C. pluricaulis extract was found to be less effective than other } \\
\text { Shankhpuspi species (Evolvulus alsinoides). }\end{array}$ \\
\hline & $\begin{array}{l}100 \mathrm{mg} / \mathrm{kg} / \text { passive avoidance } \\
\text { paradigms and an active } \\
\text { avoidance test }\end{array}$ & \multirow{2}{*}{$\begin{array}{l}\text { Piracetam } \\
\text { (Learning behavior } \\
\text { and memory } \\
\text { enhancement } \\
\text { activity) }\end{array}$} & $\begin{array}{l}\text { The } C \text {. pluricaulis extract was found to have strong memory- } \\
\text { enhancing properties. }\end{array}$ \\
\hline \multirow[t]{2}{*}{$\begin{array}{l}\text { Root part of the } \\
\text { plant/ethanolic }\end{array}$} & $\begin{array}{l}200 \mathrm{mg} / \mathrm{kg} / \mathrm{passive} \text { avoidance } \\
\text { paradigms and an active } \\
\text { avoidance test }\end{array}$ & & $\begin{array}{l}\text { When comparing the plant extract to the conventional } \\
\text { medication, the results showed that the plant extract had a } \\
\text { higher retention. }\end{array}$ \\
\hline & $\begin{array}{l}0.4 \mathrm{mg} / \mathrm{kg} / \mathrm{radioimmumoas} \mathrm{say} \\
\text { technique }\end{array}$ & $\begin{array}{l}\text { Methimazole } \\
\text { (Antithyroid } \\
\text { activity) }\end{array}$ & $\begin{array}{l}\text { The results showed that } \mathrm{T} 4 \text { to } \mathrm{T} 3 \text { conversion was the primary } \\
\text { mechanism by which } C \text {. pluricaulis extract inhibited thyroid } \\
\text { function. }\end{array}$ \\
\hline $\begin{array}{l}\text { Whole part of } \\
\text { the } \\
\text { plant/ethanolic }\end{array}$ & $\begin{array}{l}375,750 \mathrm{mg} / \mathrm{kg} / \text { gastric ulcer } \\
\text { model }\end{array}$ & $\begin{array}{l}\text { Sucralfate } \\
\text { (Antiulcer activity) }\end{array}$ & $\begin{array}{l}\text { Rather than acid pepsin, the outcome was discovered to be } \\
\text { related to an increase in mucosal defense components such as } \\
\text { mucin secretion. }\end{array}$ \\
\hline $\begin{array}{l}\text { Whole part of } \\
\text { the } \\
\text { plant/methanolic }\end{array}$ & $\begin{array}{l}200,400 \mathrm{mg} / \mathrm{kg} / \mathrm{rota} \text { rod, hole } \\
\text { board test }\end{array}$ & $\begin{array}{l}\text { Fluoxetine, } \\
\text { diazepam } \\
\text { (Antiobsessive } \\
\text { activity) }\end{array}$ & $\begin{array}{l}\text { C. pluricaulis extract can alter serotonin or dopaminergic } \\
\text { levels, according to the findings. }\end{array}$ \\
\hline \multirow[t]{2}{*}{$\begin{array}{l}\text { Whole part of } \\
\text { the } \\
\text { plant/aqueous }\end{array}$} & \multirow[t]{2}{*}{$\begin{array}{l}150 \mathrm{mg} / \mathrm{kg} / \text { Elevated plus maze, } \\
\text { Morris water maze model }\end{array}$} & \multirow{2}{*}{$\begin{array}{l}\text { Rivastigmine } \\
\text { tartrate } \\
\text { (Neuroprotective } \\
\text { activity) }\end{array}$} & $\begin{array}{l}\text { When scopolamine is induced, the } C \text {. pluricaulis extract may } \\
\text { exhibit its powerful boosting activity via anti-AChE and } \\
\text { antioxidant action, according to the findings. }\end{array}$ \\
\hline & & & $\begin{array}{l}\text { The findings showed that when aluminum chloride is induced, } \\
\text { the } C \text {. pluricaulis extract has neuroprotective properties, } \\
\text { confirming its usage in reducing aluminum toxicity. }\end{array}$ \\
\hline $\begin{array}{l}\text { Leaves part of } \\
\text { the } \\
\text { plant/ethanolic }\end{array}$ & $\begin{array}{l}200,400,600 \mathrm{mg} / \mathrm{kg} / \\
\text { thioacetamide-induced liver } \\
\text { damage in rats }\end{array}$ & $\begin{array}{l}\text { Silymarine } \\
\text { (Hepatoprotective } \\
\text { activity) }\end{array}$ & $\begin{array}{l}\text { The results showed that } C \text {. pluricaulis extract had a } \\
\text { considerable hepatoprotective effect in a rat model of } \\
\text { thioacetamide-induced liver damage. }\end{array}$ \\
\hline
\end{tabular}

Table 2. Some other plants are given ayurvedic recommendations.

\begin{tabular}{|c|c|c|}
\hline $\begin{array}{l}\text { Scientific name (Hindi } \\
\text { name) }\end{array}$ & $\begin{array}{l}\text { Chemical } \\
\text { constituents }\end{array}$ & Ayurveda suggestions \\
\hline $\begin{array}{l}\text { Bacopa monnieri } \\
\text { (Brahmi, Jalneem) }\end{array}$ & $\begin{array}{l}\text { Bacosides A, } \\
\text { B, C }\end{array}$ & $\begin{array}{l}\text { To help with hysteria, its juice is mixed with "kuth" (Costusspeciosus root) powder in } \\
\text { honey. To cure epilepsy and hysteria, it is also recommended that "kuth" and } \\
\text { "shankhapushpi" be added. It is incredibly advantageous in terms of memory retrieval. }\end{array}$ \\
\hline $\begin{array}{l}\text { Centellaasiatica } \\
\text { (Brahmi, Gotu Kola) }\end{array}$ & & $\begin{array}{l}\text { When used in amalgamation preparations, the dry plant boosts memory power. Its powder, } \\
\text { when mixed with raw cow milk and consumed, provides relief from insomnia. To relieve } \\
\text { tension, the powder is blended with pepper, honey, or cow's "ghee" (purified butter) and } \\
\text { swallowed. }\end{array}$ \\
\hline $\begin{array}{l}\text { Convolvulus microphyllus } \\
\text { (Shankhapushpi, } \\
\text { Shankahuli) }\end{array}$ & $\begin{array}{l}\text { Convoline, } \\
\text { convolamine }\end{array}$ & $\begin{array}{l}\text { Its powder is blended with milk, "bach" (Acorus calamus roots), honey, and "ghee" and } \\
\text { consumed to boost memory. Its honeyed liquid treats epilepsy, psychosis, and insanity. } \\
\text { The mind is strengthened by using dry powder alone or in combination with "bach" or } \\
\text { Indian pennywort. }\end{array}$ \\
\hline $\begin{array}{l}\text { Cuscutareflexa } \\
\text { (Amarbail, Akashbail) }\end{array}$ & $\begin{array}{l}\text { Cuscutoside } \\
\mathrm{A} \text { and } \mathrm{B}\end{array}$ & Its juice is mixed with water and used to treat brain problems. \\
\hline $\begin{array}{l}\text { Cynodondactylon } \\
\text { (Doob, Doorba) }\end{array}$ & $\begin{array}{l}\text { Flavonoids, } \beta \text { - } \\
\text { sitosterol }\end{array}$ & Madness and epilepsy can be cured with a whole plant extract. \\
\hline $\begin{array}{l}\text { Sesbania grandiflora } \\
\text { (Agastiya, Agust) }\end{array}$ & $\begin{array}{l}\text { Leucocyanidi } \\
\text { n, cyanidin, } \\
\text { triterpenoids }\end{array}$ & $\begin{array}{l}\text { In cow urine, sesban plants and black pepper are crushed and inhaled. It provides } \\
\text { immediate relief from epilepsy. A few drops of leaf or flower extract are placed in the } \\
\text { opposite nostril to relieve migraine pain. }\end{array}$ \\
\hline
\end{tabular}




\begin{tabular}{|c|c|c|c|}
\hline $\begin{array}{l}\text { Scientific name } \\
\text { name) }\end{array}$ & (Hindi & $\begin{array}{l}\text { Chemical } \\
\text { constituents }\end{array}$ & Ayurveda suggestions \\
\hline $\begin{array}{l}\text { Sidacordifolia } \\
\text { (Janglimethi, } \\
\text { Khrainti) }\end{array}$ & Bariyar, & $\begin{array}{l}\text { Sidasterone A } \\
\text { and B }\end{array}$ & $\begin{array}{l}\text { Its powder, after being cooked in milk, is given to the patient or massaged into the affected } \\
\text { area, providing relief from facial paralysis. The plant and "apamarg" (Achyranthes aspera) } \\
\text { are heated in milk until concentrated and administered to calm excessive anxiousness. }\end{array}$ \\
\hline $\begin{array}{l}\text { Withania } \\
\text { (Ashwagandha, As }\end{array}$ & agandha) & $\begin{array}{l}\text { Withaferin A, } \\
\text { withanolide A }\end{array}$ & $\begin{array}{l}\text { This plant has been used in Ayurveda for a variety of ailments as well as total bodily } \\
\text { strength. It has also been proven to be useful in the treatment of ischemia. }\end{array}$ \\
\hline
\end{tabular}

\section{Conclusions}

Popular Ayurvedic medicinal plants (Ashwagandha, Turmeric, Brahmi, Shankhpushpi, Gotu kola, and Guggulu) not only decrease brain aging and induce antistress effects, but these plants also have additional benefits too. For instance, these well-known plants have memoryenhancing effects which aid in the regeneration of neural tissues but also induce antioxidant, anti-inflammatory, anti-amyloidogenic, nutritional, and immune-supportive effects in the human body. In order to evaluate the quality of these plants, which will assist in global acceptance, scientific validation and the documentation of Ayurvedic medicines is crucial. Apart from achieving purity, the therapeutic efficacy of Ayurvedic herbal formulations might be enhanced by gaining a better understanding of their biological effects. Several studies and attempts are going in parallel these days to achieve this goal. Once it is finished, in the upcoming time, large multicenter clinical trials of Ayurvedic medicine can be planned and executed in patients with dementia and other life-threatening neurodegenerative disorders.

\section{Funding}

Nil.

\section{Acknowledgments}

Siddhartha Dan wishes to acknowledge the I.K. Gujral Punjab Technical University, Jalandhar, India, for carrying out this work and also acknowledge Ms. Anindita Rout (JWC, Jamshedpur Jharkhand) and Shilpa Rajwar (Vinoba Bhave University, Hazaribag Jharkhand).

\section{Conflicts of interests}

None.

\section{References}

1. Sofowora, A.; Ogunbodede, E.; Onayade, A. The role and place of medicinal plants in the strategies for disease prevention. Afr J Tradit Complement Altern Med. 2013, 12, 10, 210-29, https://doi.org/10.4314/ajtcam.v10i5.2.

2. Sandhya, S.; Vinod, K.R.; Sravan, K. Herbs used for brain disorders. Hygeia J D Med 2010, 2, 38-45.

3. Rao, R.V.; Descamps, O.; John, V.; Bredesen, D.E. Ayurvedic medicinal plants for Alzheimer's disease: a review. Alzheimers Res Ther. 2012, 29, 4, 22, https://doi.org/10.1186/alzrt125.

4. Younus, M.; Younus, A.; Shahbaz, I. Value of Ayurvedic medicinal plants as psychotherapeutic agents-A review. Intern J Innov Sci Engg Tech 2015, 2, 144-148.

5. Tewari, R.; Rout, P.K.; Misra, L.N. Simultaneous RP-HPLC-PDA-RI separation and quantification of pinitol content in Sesbania bispinosa vis-à-vis harvesting age. Plant Biosys - An International Journal Dealing with all Aspects of Plant Biology 2016, 151, 924-930, https://doi.org/10.1080/11263504.2016.1265612.

6. Gupta, M.; Rout, P.K.; Misra, L.N.; Gupta, P.; Singh, N.; Darokar, M.P.; Saikia, D.; et.al. Chemical composition and bioactivity of Boswellia serrata Roxb. essential oil in relation to geographical variation. 
Plant Biosys - An International Journal Dealing with all Aspects of Plant Biology 2017, 151, 4, 623-629, https://doi.org/10.1080/11263504.2016.1187681.

7. Ahmad, F.; Misra, L.; Gupta, V.K.; Darokar, M.P.; Prakash, O.; Khan, F.; Shukla, R. Synergistic effect of (+)-pinitol from Saraca asoca with $\beta$-lactam antibiotics and studies on the in silico possible mechanism. $J$ Asian Nat Prod Res. 2016, 18, 172-83, http://doi.org/10.1080/10286020.2015.1075005.

8. Ahmad, F.; Misra, L.N.; Tewari, R.; Gupta, P.; Gupta, V.K.; Darokar, M.P.; Isolation and HPLC profiling of chemical constituents of Saracaasoca bark. Indian J Chem B 2016, 55B, 353-61.

9. Ahmad, F.; Misra, L.; Tewari, R.; Gupta, P.; Mishra, P.; Shukla, R. Anti-inflammatory flavanol glycosides from Saraca asoca bark. Nat Prod Res. 2016, 30, 489-92, http://doi.org/10.1080/14786419.2015.1023728.

10. Balkrishna, A.; Misra, L.N. Ayurvedic Plants in Brain Disorders: The Herbal Hope. J Tradit Med Clin Natur 2017, 6, 221.

11. Parasuraman, S.; Thing, G.S.; Dhanaraj, S.A. Polyherbal formulation: Concept of Ayurveda. Pharmacogn Rev. 2014, 8, 73-80, https://doi.org/10.4103/0973-7847.134229.

12. Mishra, S.; Trikamji, B.; Singh, S.; Singh, P.; Nair, R. Historical perspective of Indian neurology. Ann Indian Acad Neurol. 2013, 16, 467-477, http://doi.org/10.4103/0972-2327.120422.

13. Manyam, B.V. Dementia in Ayurveda. The $J$ of Alt Comp Med 1999, 5, 81-88, https://doi.org/10.1089/acm.1999.5.81.

14. Sink, K.M.; Holden, K.F.; Yaffe, K. Pharmacological treatment of neuropsychiatric symptoms of dementia: A review of the evidence. JAMA-J AM MED ASSOC 2005, 293, 596-608.

15. Lonergan, E.; Luxenberg, J.; Colford, J.M.; Birks, J. Haloperidol for agitation in dementia. Cochrane Database of Systematic Reviews $\mathbf{2 0 0 2}$.

16. Ballard, C.; Howard, R. Neuroleptic drugs in dementia: benefits and harm. Nature Reviews Neuroscience 2006, 7, 492-500.

17. Tifratene, K.; Manera, V.; Fabre, R.; Gros, A.; Thummler, S.; Pradier, C.; David, R. Antipsychotic prescribing for Alzheimer's disease and related disorders in specialized settings from 2010 to 2014 in France: a repeated cross-sectional study. Alzheimer's research \& therapy 2017, 9, 1-10.

18. McShane, R.; Westby, M.J.; Roberts, E.; Minakaran, N.; Schneider, L.; Farrimond, L.E.; Debarros, J. Memantine for dementia. Cochrane database of systematic reviews 2019.

19. Hogan, D.B.; Bailey, P.; Black, S.; Carswell, A.; Chertkow, H.; Clarke, B.; Thorpe, L. Diagnosis and treatment of dementia: 5. Nonpharmacologic and pharmacologic therapy for mild to moderate dementia. Cmaj 2008, 179, 1019-1026.

20. Peisah, C.; Chan, D.K.Y.; McKay, R.; Kurrle, S.E.; Reutens, S.G. Practical guidelines for the acute emergency sedation of the severely agitated older patient. Internal Medicine Journal 2011, 41, 651-657.

21. Akhlaq, A.; Farooqui, T.F.; Anil, M.; JolinHwee-Jing, O.; Wei-Yi, Ong. Ayurvedic Medicine for the Treatment of Dementia: Mechanistic Aspects. Evidence-Based Complementary and Alternative Medicine 2018, https://doi.org/10.1155/2018/2481076.

22. Brahma, S.K.; Debnath, P.K. Therapeutic importance of Rasayana drugs with special reference to their multidimensional actions. Aryavaidyan. 2003, 16, 160-3.

23. Rege, N.N.; Thatte, U.M.; Dahanukar, S.A. Adaptogenic properties of six rasayana herbs used in ayurvedic medicine, Phytotherapy Research 1999, 13, 275-291.

24. Schlebusch, L.; Bosch, B.A.; Polglase, G.; Kleinschmidt, I.; Pillay, B.J.; Cassimjee, M.H. A double-blind, placebo-controlled, double-centre study of the effects of an oral multivitamin-mineral combination on stress. South African Medical Journal 2000, 90, 1216-1223.

25. Murphy, B.M.; Frigo, L.C. Development, implementation, and results of a successful multidisciplinary adverse drug reaction reporting program in a university teaching hospital. Hospital Pharmacy Journal 1993, 28, 1199-1204.

26. Govindarajan, R.; Vijayakumar, M.; Pushpangadan, P. Antioxidant approach to disease management and the role of "Rasayana" herbs of Ayurveda. Journal of Ethnopharmacology 2005, 99, 165-178.

27. Manyam, B.V; Dementia in Ayurveda.J Altern Complement Med. 1999, 5, 81-88, https://doi.org/10.1089/acm.1999.5.81.

28. Mishra, L.C; Singh, B.B.; Dagenais, S. Scientific basis for the therapeutic use of Withaniasomnifera (ashwagandha): a review. Altern Med Rev. 2000, 5, 334-346.

29. Hassan, M.A.G.; Balasubramanian, R.; Masoud, A.D; Burkan, Z.E.; Sughir, A. Role of medicinal plants in neurodegenerative diseases with special emphasis to Alzheimer's disease. Int J Phytopharmacol 2014, 5, 454462. 
30. Perry, E.; Howe, M.R. Medicinal plants and dementia therapy: Herbal hopes for brain aging. CNS NeurosciTherap 2011, 17, 683-698.

31. Goswami, S.; Saoji, A.; Kumar, N.; Thawani, V.; Tiwari, M.; Thawani, M. Effect of Bacopa monnieri on Cognitive functions in Alzheimer's disease patients. Int J Collab Res Intern Med Public Health 2011, 3, 285 93.

32. Singh, S. Phytochemical analysis of leaf callus of Bacopa monnieri L. Int J Sci Res Pub 2012, 2, 1-3, https://doi.org/10.13140/RG.2.2.17307.46882.

33. Russo, A.; Borrelli, F. Bacopa monniera, a reputed nootropic plant: an overview. Phytomedicine 2005, 12 , 305-317, https://doi.org/10.1016/j.phymed.2003.12.008.

34. Aguiar, S.; Borowski, T. Neuropharmacological review of the nootropic herb Bacopa monnieri. Rejuvenation Res 2013, 16, 313-326, https://doi.org/10.1089/rej.2013.1431.

35. Carlo, C.; William, L.; Michael, L. Effects of a standardized Bacopa monnieri extract on cognitive performance, anxiety, and depression in the elderly: A randomized, double-blind, placebo-controlled trial. J Altern Complement Med 2008, 14, 707-713, https://doi.org/10.1089/acm.2008.0018.

36. Uabundit, N.; Wattanathorn, J.; Mucimapura, S.; Ingkaninan, K. Cognitive enhancement and neuroprotective effects of Bacopa monnieri in Alzheimer's disease model. J Ethnopharmacol 2010, 127, 26-31, https://doi.org/10.1016/j.jep.2009.09.056.

37. Monograph. Bacopa monniera. Sci. Rev. Altern. Med. 2004, 9, 79-85, https://pubmed.ncbi.nlm.nih.gov/15005647.

38. Shinomol, G.K.; Muralidhara, Bharat. M.M. Exploring the role of 'Brahmi' (Bacopa monnieri and Centella asiatica) in brain function and therapy. Recent Pat Endocr Metab Immune Drug Discov. 2011, 5, 33-49, https://doi.org/10.2174/187221411794351833.

39. Singh, H.K.; Dhawan, B.N. Effect of Bacopa monniera Linn. (brahmi) extract on avoidance responses in rat. J Ethnopharmacol. 1982, 5, 205-214, https://doi.org/10.1016/0378-8741(82)90044-7.

40. Bhattacharya, S.K.; Bhattacharya, A.; Kumar, A. Antioxidant activity of Bacopa monniera in rat frontal cortex, striatum and hippocampus. Phytother Res. 2000, 14, 174-179, https://doi.org/10.1002/(sici)10991573(200005).

41. Limpeanchob, N.; Jaipan, S.; Rattana, karuna, S.; et al. Neuroprotective effect of Bacopa monnieri on betaamyloid-induced cell death in primary cortical culture. J Ethnopharmacol. 2008, 120, 112-127, https://doi.org/10.1016/j.jep.2008.07.039.

42. Kumar, V. Potential medicinal plants for CNS disorders: an overview. Phytother Res 2006, 20, 1023-1035, https://doi.org/doi: 10.1002/ptr.1970.

43. Bacopa monniera. Monograph. Altern Med Rev 2004, 9, 79-85.

44. Dhanasekaran, M.; Tharakan, B.; Holcomb, L.A.; Hitt, A.R.; Young, K.A.; Manyam, B.V. Neuroprotective mechanisms of ayurvedic antidementia botanical Bacopa monniera. Phytother Res 2007, 21, 965-969, https://doi.org/10.1002/ptr.2195.

45. Stough, C.; Downey, L.A.; Lloyd, J.; Silber, B.; Redman, S.; Hutchison, C.; Wesnes, K.; Nathan, P.J. Examining the nootropic eff ects of a special extract of Bacopa monniera on human cognitive functioning: 90 day double-blind placebocontrolled randomized trial. Phytother Res 2008, 22, 1629-1634, https://doi.org/doi: 10.1002/ptr.2537.

46. Singh, R.H.; Narsimhamurthy, K.; Singh, G. Neuronutrient impact of Ayurvedic Rasayana therapy in brain aging. Biogerontology 2008, 9, 369-374, https://doi.org/10.1007/s10522-008-9185-z.

47. Abdul, M.; Aimi, S.; et al. "Bacopa monnieri, a Neuroprotective Lead in Alzheimer Disease: A Review on Its Properties, Mechanisms of Action, and Preclinical and Clinical Studies." Drug target insights 2019, 13, https://doi.org/10.1177/1177392819866412.

48. Saraf, M.K.; Prabhakar, S.; Khanduja, K.L.; Anand, A. Bacopa monniera attenuates scopolamine-induced impairment of spatial memory in mice. Evid Based Complement Alternat Med. 2011, https://doi.org/10.1093/ecam/neq038.

49. Mukherjee, S.; Dugad, S.; Bhandare, R.; et al. Evaluation of comparative free-radical quenching potential of Brahmi (Bacopa monnieri) and Mandookparni (Centella asiatica). Ayu. 2011, 32, 258264, https://doi.org/10.4103/0974-8520.92549.

50. Holcomb, L.A.; Dhanasekaran, M.; Hitt, R.; Young, K.A.; Riggs, M.; Manyam, B.V. Bacopa monniera extract reduces amyloid levels in PSAPP mice.J Alzheimers Dis. 2006, 9, 243-251, https://doi.org/10.3233/jad-2006-9303. 
51. Limpeanchob, N.; Jaipan, S.; Rattanakaruna, S.; Phrompittayarat, W.; Ingkaninan K. Neuroprotective effect of Bacopa monnieri on beta-amyloid-induced cell death in primary cortical culture. J Ethnopharmacol. 2008, 120, 112-117, https://doi.org/10.1016/j.jep.2008.07.039.

52. Rajan, K.E.; Preethi, J.; Singh, H.K. Molecular and functional characterization of Bacopa monniera: a retrospective review. Evid Based Complement Alternat Med. 2015, https://doi.org/10.1155/2015/945217.

53. Chakravarty, A.K.; Sarkar, T.; Masuda, K.; Shiojima, K.; Nakane, T.; Kawahara, N. Bacopaside I and II: two pseudojujubogenin glycosides from Bacopa monniera. Phytochemistry. 2001, 58, 553-556, https://doi.org/10.1016/s0031-9422(01)00275-8.

54. Pardridge, W.M. Blood-brain barrier biology and methodology. J Neurovirol. 1999, 5, 556-569, https://doi.org/10.3109/1355028990902.

55. De, K.; Chandra, S.; Misra ,M. Evaluation of the biological effect of brahmi (Bacopa monnieri Linn) extract on the biodistribution of technetium-99m radiopharmaceuticals. Life Sci J. 2008, 5, 45-49.

56. Watkins, P.B. The barrier function of CYP3A4 and P-glycoprotein in the small bowel. Adv Drug Deliv Rev. 1997, 27, 161-170, https://doi.org/10.1016/s0169-409x(97)00041-0.

57. Dubey, T.; Chinnathambi, S. Brahmi (Bacopa monnieri): An ayurvedic herb against the Alzheimer's disease, Arch. Biochem. Biophys. 2019, 676, https://doi.org/10.1016/j.abb.2019.108153.

58. Singh, R.; Panduri, J.; Kumar, D.; et al. Evaluation of memory enhancing clinically available standardized extract of Bacopa monniera on P-glycoprotein and cytochrome P450 3A in Sprague-Dawley rats. PLoS ONE. 2013, 8, https://doi.org/10.1371/journal.pone.0072517.

59. Kumar, S.; Christopher, J.S.; Edward, J.O. Kinetics of acetylcholinesterase inhibition by an aqueous extract of Withania somnifera roots. Int. J. Pharm. Sci.Res. 2011, 2, 1188-92, http://dx.doi.org/10.13040/IJPSR.0975-8232.

60. Sandhu, J.S.; Shah, B.; Shenoy, S.; Chauhan, S.; Lavekar, G.S.; Padhi, M.M. Effects of Withania somnifera (Ashwagandha) and Terminalia arjuna (Arjuna) on physical performance and cardiorespiratory endurance in healthy young adults. Int J Ayurveda Res. 2010, 1, 144-9, http://dx.doi.org/10.4103/0974-7788.72485.

61. Russo, A.; Izzo, A.A.; Cardile, V.; et al. Indian medicinal plants as antiradicals and DNA cleavage protectors. Phytomedicine. 2001, 8, 125-132, http://dx.doi.org/10.1078/0944-7113-00021.

62. Monograph. Withania somnifera. Sci. Rev. Altern. Med. 2004, 9, 211-214, https://pubmed.ncbi.nlm.nih.gov/15253680.

63. Auddy, B.; Hazra, J.; Mitra, A.; et al. A standardized Withania somnifera extract signifi cantly reduces stressrelated parameters in chronically stressed humans: a double-blind randomized, placebocontrolled study. JANA 2008, 11, 50-56.

64. Matsuda, H.; Murakami, T.; Kishi, A.; et al. Structures of withanosides I, II, III, IV, V, VI, and VII, new withanolide glycosides, from the roots of Indian Withania somnifera DUNAL and inhibitory activity for tachyphylaxis to clonidine in isolated guinea-pig ileum. Bioorg Med Chem. 2001, 9, 14991507, http://dx.doi.org/10.1016/s0968-0896(01)00024-4.

65. Jayaprakasam, B.; Padmanabhan, K.; Nair, M.G. Withanamides in Withania somnifera fruit protects PC-12 cells from beta-amyloid responsible for Alzheimer's disease. Phytother Res. 2010, 24, 859863, http://dx.doi.org/ 10.1002/ptr.3033.

66. Kumar, S.; Harris, R.J.; Seal, C.J.; et al. An aqueous extract of Withania somnifera root inhibits amyloid beta fibril formation in vitro. Phytother Res. 2012, 26, 113-117, http://dx.doi.org/10.1002/ptr.3512.

67. Schliebs, R.; Liebmann, A.; Bhattacharya, S.K.; et al. Systemic administration of defi ned extracts from Withania somnifera (Indian Ginseng) and Shilajit differentially affects cholinergic but not glutamatergic and GABAergic markers in rat brain. Neurochem Int. 1997, 30, 181-190. http://dx.doi.org/10.1016/s01970186(96)00025-3.

68. Kuboyama, T.; Tohda, C.; Komatsu, K. Neuritic regeneration and synaptic reconstruction induced by withanolide A. Br J Pharmacol. 2005, 144, 961-971, http://dx.doi.org/ 10.1038/sj.bjp.0706122.

69. Mishra, L.C.; Singh, B.B.; Dagenais, S, Scientific basis for the therapeutic use of Withania somnifera (ashwagandha): a review. Altern Med Rev 2000, 5, 334-346, https://pubmed.ncbi.nlm.nih.gov/10956379.

70. Dhuley, J.N. Eff ect of ashwagandha on lipid peroxidation in stress-induced animals. J Ethnopharmacol. 1998, 60, 173-178. http://dx.doi.org/10.1016/s0378-8741(97)00151-7.

71. Parihar, M.S.; Hemnani, T. Phenolic antioxidants attenuate hippocampal neuronal cell damage against kainic acid induced excitotoxicity. J Biosci 2003, 28, 121-128, https://doi.org/10.1007/BF02970142.

72. Tohda, C.; Kuboyama, T.; Komatsu, K. Search for natural products related to regeneration of the neuronal network. Neurosignals 2005, 14, 34-45, https://doi.org/10.1159/000085384. 
73. Kuboyama, T.; Tohda, C.; Zhao, J.; Nakamura, N.; Hattori, M.; Komatsu, K. Axon- or dendrite-predominant outgrowth induced by constituents from Ashwagandha. Neuroreport 2002, 13, 1715-1720.

74. Kumar, Vikas \& Dey, Amitabha \& Hadimani, Mallinath \& Marković, Tatjana \& Emerald, Mila. (2015). Chemistry and pharmacology of Withania somnifera: An update. TANG [Humanitas Medicine]. 5, 1-13, https://doi.org/10.5667/tang.2014.0030.

75. Bihaqi, S.W.; Sharma, M.; Singh, A.P.; Tiwari, M. Neuroprotective role of Convolvulus pluricaulis on aluminium induced neurotoxicity in rat brain. J Ethnopharmacol. 2009, 124, 409-415, https://doi.org/10.1016/j.jep.2009.05.038.

76. Malik, J.; Karan, M.; Vasisht, K. Noo tropic, anxiolytic and CNS-depressant studies on diff erent plant sources of shankhpushpi. Pharm Biol 2011, 49, 1234-1242, https://doi.org/10.3109/13880209.2011.584539.

77. Sethiya, N.K.; Nahata, A.; Mishra, S.H.; Dixit, V.K. An update on Shankhpushpi, a cognition-boosting Ayurvedic medicine. Zhong Xi Yi Jie He Xие Bao 2009, 7, 1001-1022, https://doi.org/10.3736/jcim20091101.

78. Kumar, V. Potential medicinal plants for CNS disorders: an overview. Phytother Res 2006, 20, 1023-1035, https://doi.org/10.1002/ptr.1970.

79. Singh, R.H.; Narsimhamurthy, K.; Sing, h.G. Neuronutrient impact of Ayurvedic Rasayana therapy in brain aging. Biogerontology 2008, 9, 369-374, https://doi.org/10.1007/s10522-008-9185-z.

80. Nahata, A.; Patil, U.K.; Dixit, V.K. Effect of Convulvulus pluricaulis Choisy. on learning behaviour and memory enhancement activity in rodents. Nat Prod Res 2008, 22, 1472-1482, https://doi.org/10.1080/14786410802214199.

81. Nahata, A.; Patil, U.K.; Dixit, V.K. Effect of Evolvulus alsinoides Linn. on learning behavior and memory enhancement activity in rodents. Phytother Res 2010, 24, 486-493, https://doi.org/10.1002/ptr.2932.

82. Rai, K.S.; Murthy, K.D.; Karanth, K.S.; Nalini, K.; Rao, M.S.; Srinivasan, K.K. Clitoria ternatea root extract enhances acetylcholine content in rat hippocampus. Fitoterapia 2002, 73, 685-689, https://doi.org/10.1016/s0367-326x(02)00249-6.

83. Rai, K.S.; Murthy, K.D.; Karanth, K.S.; Rao, M.S. Clitoria ternatea (Linn) root extract treatment during growth spurt period enhances learning and memory in rats. Indian J Physiol Pharmacol 2001, 45, 305-313.

84. Taranalli, A.D.; Cheeramkuzhy, T.C. Influence of Clitoria ternatea extracts on memory and central cholinergic activity in rats. Pharm Biol 2000, 38, 51-56.

85. Singh, G.K.; and Bhandari, A. 2000. Text book of Pharmacognosy 1st edn. New Delhi: CBS Publishers.

86. Sharma, K.; Bhatnagar, M.; and Kulkarni, S.K. Effect of Convolvulus pluricaulis Choisy and Asparagus racemosus Willd on learning and memory in young and old mice: a comparative evaluation. Indian J Exp Biol 2010, 48, 479-485.

87. Gupta, A.K.; Tandon, N.; Sharma, M. Quality standards of Indian medicinal plants. New Delhi: Indian Council of Medical Research 2005.

88. Sethiya, N.K.; Nahata, A.; Mishra, S.H.; Dixit, V.K. An update on Shankhpushpi, a cognition-boosting Ayurvedic medicine. Zhong Xi Yi Jie He Xue Bao 2009, 7, 1001-1022

89. Bihaqi, S.W.; Sharma, M.; Singh, A.P.; Tiwari, M. Neuroprotective role of Convolvulus pluricaulis on aluminium induced neurotoxicity in rat brain. J Ethnopharmacol. 2009, 124, 409-15.

90. Verma, S.; Sinha, R.; Kumar, P.; Amin, F.; Jain, J.; Tanwar, S. Study of Convolvulus pluricaulis for antioxidant and anticonvulsant activity. Cent Nerv Syst Agents Med Chem 2012, 12, 55-59.

91. Dhingra, D.; Valecha, R.; Screening for antidepressant-like activity of Convolvulus pluricaulis Choisy in mice. Pharmacologyonline 2007, 1, 262-278.

92. Nahata, A.; Patil, U.K.; Dixit, V.K. Anxiolytic activity of Evolvulus alsinoides and Convulvulus pluricaulis Choisy in rodents. Pharm Biol 2009, 47, 444-451.

93. Sharma, K.; Arora, V.; Rana, A.C.; Bhatnagar, M. Anxiolytic effect of Convolvulus pluricaulis Choisy petals on elevated plus maze model of anxiety in mice. J Herbal Med Toxicol 2009, 3, 41-46.

94. Sharma, K.; Bhatnagar, M.; Kulkarni, S.K. Effect of Convolvulus pluricaulis Choisy and Asparagus racemosus wild on learning and memory in young and old mice : a comparative evaluation. Indian J Exp Biol 2010, 48, 479-485.

95. Nahata, A.; Patil, U.K.; Dixit, V.K. Effect of Convulvulus pluricaulis Choisy on learning behaviour and memory enhancement activity in rodents. Nat Prod Res 2008, 22, 1472-1482.

96. Panda, S.; Kar, A. Inhibition of T3 production in levothyroxinetreated female mice by the root extract of Convolvulus pluricaulis. Horm Metab Res 2001, 33, 16-18.

97. Sairam, K.; Rao. C.V.; Goel, R.K. Effect of Convolvulus pluricaulis Choisy on gastric ulceration and secretion in rats. Indian J Exp Biol 2001, 39, 350-354. 
98. Subramani, R.; Anand, M.; Muralidharan, P. Effect of Convolvulus pluricaulis Choisy in obsessive compulsive disorder using animal models. India: PharmaTutor EduLabs 2008-2013, https://www.pharmatutor.org/articles/effect-of-convolvuluspluricaulis-in-obsessive-compulsive-disorderusing-animalmodels.

99. Bihaqi, S.W.; Singh, A.P.; Tiwari, M. In vivo investigation of the neuroprotective property of Convolvulus pluricaulis Choisy in scopolamine-induced cognitive impairments in Wistar rats. Indian J Pharmacol. 2011, 43, 520-525.

100.Bihaqi, S.W.; Sharma, M.; Singh, A.P.; Tiwari, M. Neuroprotective role of Convolvulus pluricaulis Choisy on aluminium induced neurotoxicity in rat brain. J Ethnopharmacologicol. 2009, 124, 409-415.

101.Ravichandra, V.D.; Ramesh, C.; Sridhar, K.A. Hepatoprotective potentials of aqueous extract of Convolvulus pluricaulis against thioacetamide induced liver damage in rats. Biomed Aging Pathol 2013, 3, 131-135.

102. Verma, S.; Sinha, R.; Singh, V.; Tanwar, S.; Godara, M. Antibacterial activity of methanolic extract of whole plant of Convolvulus pluricaulis Choisy. J Pharm Res. 2011, 4, 4450.

103.Bihaqi, S.W.; Singh, A.P.; Tiwari, M. Supplementation of Convolvulus pluricaulis Choisy attenuates scopolamine-induced increased tau and amyloid precursor protein (A $\beta$ PP) expression in rat brain. Indian $J$ Pharmacol. 2012, 44, 593-598.

104. Kothiyal, P.; Rawat, M.S. Comparative nootropic effect of Evolvulus alsinoides and Convolvulus pluricaulis Choisy. Int J Pharma Bio Sci. 2011, 2, 616-621.

105. Balkrishna, A.; Misra, L.N. Ayurvedic Plants in Brain Disorders: The Herbal Hope. J Tradit Med Clin Natur 2017, 6:221.

106.Pant, M.; Dan, S.; Pant, S.; et al. Progression in Alzheimer's Disease Correlates With Epigenetics and Cerebral Formaldehyde: From Potential Hereditary Mechanism and Environmental Factors to Therapeutic Measures. Curr Pharmacol Rep 2021, 7, 187-205, https://doi.org/10.1007/s40495-021-00265-6.

107.Dan, S.; Sharma, D.; Ojha, H.; Pathak, M.; Singhal, R. Therapeutic and Diagnostic Applications of Nanocomposites in the Treatment Alzheimer's Disease Studies. Biointerface Research in Applied Chemistry 2021, 12(1), 940-960, https://doi.org/10.33263/BRIAC121.940960. 